\title{
Unpacking the downside of sustentasie on African theology and theologians: a need for contextual black theology as a liberative ingredient for the black Reformed churches
}

Author:
Elijah Baloyi ${ }^{1}$
Affiliation:
${ }^{1}$ College of Human Sciences,
University of South Africa,
South Africa
Corresponding author:
Elijah Baloyi,
baloye@unisa.ac.za
Dates:
Received: 21 Aug. 2015
Accepted: 24 Dec. 2015
Published: 29 Aug. 2016
code with your
How to cite this article:
Baloyi, E., 2016, 'Unpacking
the downside of sustentasie
on African theology and
theologians: a need for
contextual black theology as
a liberative ingredient for the
black Reformed churches',
HTS Teologiese Studies/
Theological Studies $72(1)$,
a3161. http://dx.doi.
org/10.4102/hts.v72i1.3161
Read online.
Copyright:
(C) 2016. The Authors.
Licensee: AOSIS. This work
is licensed under the
Creative Commons
Attribution License.

The practice of the black church being a follower of the leading white church is a continuous process in the Gereformeerde Kerke in Suid Afrika (or Reformed Churches in South Africa in English). This makes it difficult to contextualise Reformed Theology to address African challenges and problems. There are many reasons for the subordination of the black theologians, but for the sake of this article, I identified the issue of sustentasie ${ }^{1}$ as one of the causes. The lack of financial independence implies that the black church ${ }^{2}$ cannot determine their destiny by revising, transforming and even Africanising their theology to fit into their context and challenges, since that would mean they are biting the hand that feeds them. This article will argue that it is time that Africans stop being a theological duplication of the Western theologies and that they take responsibility to ensure that their theology addresses the immediate situation of the Black Reformed people (contextualised) with or without the support from the white church.

\section{Introduction}

The Black Reformed Church within the Gereformeerde Kerke in Suid Afrika (GKSA), even after the 20 years into democracy had been faced with challenges of white domination as far as the theological discourse is concerned. I want to use this article as an opportunity to raise some of the issues which play a role in the continued subjection of one church by the other.

The old Black Reformed Church in which the author was born is still referred to as 'die jong kerke' The young churches (Lekalakala 2002:10). This church has been I existence for some time now, as in 1989 it was declared independent where it was allowed by the synod to have its own church council to run its own affairs. This is as a result of paternalism, which dictates that the financially dependent church should continue to be inferior to the mother church. Although it is not the main focus of the article, many white Reformed Churches enjoy supporting the black Church financially, amongst other reasons because they want to control, dominate, subject and even gain respect over them. The spirit of ownership over the supported churches can be summarised by statements such as 'Ons kerke vir hulle and ons teologiese skool vir hulle' (Baloyi 2010:425) Without taking away that some may be supporting because of passion and love for the black church, there are those who are doing it to gain power and have unquestionable authority over the recipients. This is correctly argued by Ramantswana (2015:13) in indicating the 'masterminding' attitude that come from the funders. If the dependent church speaks her mind, that is 'to bite the hand that feeds it' (Lekalakala 2002:14). I am in full agreement with Kiyosaki's (2012:79) golden rule that says 'He who has the gold makes the rules'.

The challenges of the black Reformed Church ${ }^{3}$ continue to haunt them, while the black theologians are not helpful in some of these challenges. These are the black GKSA theologians and pastors who, amongst other challenges, are failing to give answers, for instance towards poverty, continued gender inequality in the church and other related problems in their churches. Amongst other things, three issues are outstanding for the author as reasons supporting my argument above:

- For 21 years into democracy, the discussion on the issue of the unity between black and white Reformed churches is not yielding any desired result. The 2015 almanac of the Reformed

1.Sustentasie refers loosely to the act of the white wealthier church financially subsidising the black poor church. In Tsonga "Ku hlayisiwa ka kereke yo pfumala hi kereke leyi nga na mali, ngopfu-ngupfu ta valungu. Leswi swi katsa ku famba vanhu va kombela timali leti ha tona va faneleke ku aka kereke hambi ku ri ku holela vafundzhisi va vona'. (Translated as: This includes when churches go asking for tona va faneleke ku aka kereke hambi ku ri ku holela vafundzhisi
money to erect church buildings as well as to pay their pastors).

2.Black church in this article is used to refer to the Black Reformed Church, often referred to as Gereformeerde Kerke in S.A.

3.With 'Reformed' in this article I refer to the Reformed churches known as Gereformeerde Kerke in Suid Afrika-GKSA (English RCSA). 
Churches in South Africa (RCSA) indicates that the socalled consulates ${ }^{4}$ of the Classis Limpopo (which stretches from Mokopane to Lusaka in Zambia, inclusive of black and white churches) are classified in racial lines (Almanak 2015). This means white pastors have been appointed as consulents of white churches, while blacks can only be consulents of black churches, under the same classis. The true implication of this is that white churches will be addressing their own issues, while the black church does likewise, under the same classis. For me this denies the unity of the church, for which Calvin, the founder would have crossed ten seas (Van Wyk 2010:301-316).

- There is a concern about the dearth of African leadership which is caused, amongst other things, by the lack of relevant theological tools (for training) in theological seminaries and universities (Tshaka 2013:182). The truth is that the theological academy in South Africa is dominated by Western epistemologies which failed to give answers to practical matters of the African community. This means we will have pastors who fail to uproot the challenges of their own congregations.

- The black church in rural areas is the most affected one by the decision that bares women from ordination. The decision was handed down in 2003 (Deventer 2005:68). This is because most rural villages are left with women and elderly due to the fact that men are in towns and cities, fending for their families. This is connected to the historical forced removals which prevented black people to be closer to places designated for white exclusive use during apartheid regime (Kgatla 2013:120). The black ministers and theologians are quiet on the matter. There is a lack of black voices in the engagement of women ordination.

- Issues which influence and play role in shaping the spirituality of black people are undermined and neglected. Amongst others, examples of witchcraft (as argued by Baloyi in his previous work), poverty and healing ministry (Manala 2015) as factors causing an exodus of membership are not entertained (Theron \& De Wit 2009:153).

It is my argument that the neglect of these key ministry challenges among black theologians of GKSA is caused (at least partly) by a captive, 'colonised' mind or dependency syndrome brought about by the practice of 'subsidy'. It is an old cry in the theological debates that besides its support for apartheid, the Reformed theology has been accused of its irrelevance towards the African challenges.

\section{Background}

It will be unfair for the author to think that he is the first to raise problems related to the subordination of the black church by the white church as a consequence of financial dependence. Roland Allen (1960 [1912]:146), an Anglican theologian involved in mission in Asia a hundred years ago, complained about the lack of initiatives from the converted indigenous Christians due the fact that missionaries kept control. In the early 1970s John Gatu, who was a general secretary of the Presbyterian Church in East Africa, asked for a moratorium on European and American support for African churches (Adamo \& Enuwosa 2004:1).

Despite the fact that many churches were affected by this practice, the focus of this article is confined to the RCSA, which call themselves 'Gereformeerde Kerke' in Afrikaans. The churches under focus are part of a bigger family of Calvinism, which came as a result of John Calvin's reaction towards the Catholic church at that time, more than 500 years ago. It is his theology that was shipped to and planted in Africa many centuries ago. These are the churches which pride themselves with the five solas, which are: 'Sola scriptura (Scripture alone, as our highest authority), sola fide (by faith alone), sola gratia (by grace alone), solo Christo (through Christ alone) and soli Deo gloria (to God alone the glory)' (Strawbridge 1993:1). The unprecedented criticism of this church for its role in supporting the apartheid can still be echoed in many corners of the country. One cannot turn a blind eye to ignore that the forced removals (Kgatla 2013:120) as well as other apartheid policies ensured that the undeservedly rich whites were made to be politically rich masters of the undeservedly poor black majority. Although the Reformed theology played its role in capacitating apartheid, it can be noted that some of its theologians later find out some possibilities of denouncing and criticising it. The inequality paved the way for Western missionaries to penetrate the dependent mind of the black church so easily. It is partly for this reason that Mashele (2014:11) argues that a great deal might have changed since the 19th century, but the fundamental status of black people as servants of whites remains unchanged - no matter how vehemently some white people deny it. That way the white church managed to make the black Reformed perpetual beggars. They were chained and controlled by the financial assistance they received from the white church.

This view is reiterated by Speckman and Kaufmann, who said:

What made it difficult for ministers and congregations of the three black Reformed Churches to express their opposition to apartheid, even if they wanted to, was the fact that they were financially dependent on subsidies from DRC (white) congregations, presbyteries or synods. This economic dependence entrenched the power of white Christians and the disempowerment of black Christians. It also reinforced racist attitudes, because they were powerless and dependent on the whites. (Speckman \& Kaufmann 2001:252)

It was perhaps for this reason that Klippies Kritzinger and other white pastors excused themselves from the white salaries from their white church brothers in order to liberate their churches from dependency (Banda 2009:116). In other words, it is money more than reality that counts. The betrayal of the black church's need by their own ministers, who have become 'working boys for the white church' among the black community, should be addressed and eliminated, and this is the gist of the lecture. Even if the status of self-governing is 
attained by the black church, the fact that she lacks the financial muscle hinders her from exercising efficient selfgovernance (Manala 2009:3).

A clear case is that within the Reformed Church fraternity, particularly the Gereformeerde Kerke (Reformed Churches), the white church is still dominant in terms of decisionmaking. Sustentasie was instituted to ensure that poor churches are assisted to carry on with their calling. This informs the Tsonga belief that: 'Mpandwa wo nyikiwa awu ondli n'wana' ('the given slice of porridge cannot bring up a child'). Steve Biko (1978:63) made this very clear by saying: 'Many black church men have been in the struggle of addressing that whites are in power within the churches, the churches are modelled on Western lines which white people know best'.

\section{Some of the challenges faced by the black church}

Amongst the challenges the black Reformed Churches are faced with, the sustentasie is adding issues such as the contradiction of true Calvinism which advocates equality between church office bearers. The irrelevance of theology towards contemporary challenges and decolonisation of the black church also mounts up. On the other hand, the selfhatred of the black masses accompanied by the poor image of the black pastors becomes the order of the day. These are issues the author is going to elaborate on below.

\section{Betrayal or contradiction of true Calvinism}

The financial dependence of the black church opens the abuse and misunderstanding of the Reformed Church order and principles in few ways. For instance, the Reformed Church (GKSA) order article 84 says: 'No church, minister of the word, elder or deacon shall in any way dominate other churches, ministers, elders or deacons respectively' (Du Plooy 2003:124). According to The Vine's Dictionary, the original Greek word for 'dominion' includes 'control, force, strength, often oppressive, govern, or rule by superior power or authority or power', which is very practical when most white churches demand bank statements and other reports from the indigenous church they supported financially (Vine 1981:332-334) The 'Gereformeerde Kerke' are convinced that the scripture teaches that each congregation is a complete manifestation of the body of Christ. Therefore, for this reason, Christ rules the church through the ordained office-bearers, and that means there is equality between all office bearers as well as between autonomous congregations. This connected well with the Reformation agenda which from Romans 3:22-24 argues that the righteousness is through faith alone and there is no distinction between people. For the sake of this study, the emphasis is on 'faith alone' (sola fide) which assisted in incapacitating many people to think that good works, including giving in their churches are not important. It cannot be ignored that the other part of this verse which says 'no distinction from people' also had its political influence to South Africans, which is not going to be the focus of this study. Besides that, the indigenous church is dominated because it cannot be allowed to take decisions which may be against their mother church. This control or dominance is what contradicts the mentioned church order article and the Bible. The domination of the white church is an entrenchment of racial inequality which goes against the Biblical teachings. This inequality was abolished legally and constitutionally more than 21 years ago in South Africa.

In the same vein, according to Burger (2010:318), Calvin, the founder of these churches believed in the autonomy of the local church. Calvin allowed local congregations to develop their own standards such as church order and liturgy that would fit their own contexts. With this autonomy, it would be assumed that every local church is at liberty to contextualise their own liturgics, without interference from churches outside (Hanko 1996:16). The concept 'autonomy' means 'self-governance' which allows the local church the powers to take decisions that will determine their own destiny. However, it has never been easy for any indigenous Reformed Church to be free from dependence until today.

\section{An irrelevant theology}

The exodus of members from mainline churches, particularly Reformed churches to African independent churches, pentecostal and charismatic churches, which Theron and De Wit (2009:153) confirmed, should raise serious concerns. If one may ask the reason why, there are few possibilities for this:

Mbiti (in Cassidy 1976:268) vowed this a long time ago saying: 'Christianity has to lose its foreignness and become relevant, indigenous and deeply involved in the affairs of our continent, as a participant, not as a spectator'. Joining him in the argument are Waruta and Kinothi (2000:18) who argue that 'the training curriculum has not been geared to the African cultural milieu, and the theology is not addressing African people within their immediate situations and circumstances'.

The issue of the ignorance to attend to the issue of healing ministry in the Maranatha church (Manala 2015), which is exactly the case with RCSA, opens a loophole for the members to seek churches which will address this pertinent challenge. Healing leads many people into being Reformed by Sunday, but during the week they seek healing either from traditional healers or seeking the prayers accompanied by laying of hands elsewhere. Some are sneaking in and out of the church, while others decide to take their membership to churches where they receive healing prayers.

According to Baloyi (2014:5), the churches initiated by white people from the West, such as the Reformed Church, do not really regard a discussion about witchcraft as an important topic. Gijswijt-Hofstra (1999:110) sings the same tune when he argues that mainline churches, such as the Protestant churches that arose from the Reformation, treat witchcraft as mere superstition and allegation. This article does not intend 
to argue whether witchcraft exists or not, but it argues the fact that Reformed theology and other theologies demonised and avoided this topic in theological discourse. It is in the same vein that Tiyo Soga (in Williams 1978:80) argued that Western European Christian morality condemned many things within black society as barbaric and unacceptable. This has seen many Christians seeking answers elsewhere, while Reformed theologians continue to pride themselves that they have the highest academic qualifications (Tshaka 2009:7). The irrelevance of European theologies (Reformed included) to the African context is that black peoples' spirituality issues are always criticised and labelled as paganism. I lastly quote Steve Biko (1978) who openly said:

The white Christians within the churches are preventing the church from assuming its natural character in the South African context, and therefore preventing it from being relevant to the black man's situation. ((p. :63)

\section{Decolonising the black church}

Many Reformed people are presently hosted in church buildings that they do not own, because they are there at the mercy of white congregations that built them many years ago, hence the statement 'Hulle kerke vir ons' (Meaning their churches for us - in Baloyi 2010:425). While some white churches own church buildings four or five hundred kilometres away from their cities, other churches, from overseas, own church buildings in South Africa. That is in line with what Modise argues when saying: 'The black church buildings are still on land owned by white churches' (Modise 2011:1). This means that a black person has been placed there at the mercy of the white church. Black congregants need toleration of the owners of the building to continue their worship in those buildings. I have been informed of many mainline churches that are struggling to get ownership of the missionary church buildings and missionary houses. In his paper entitled, 'The call to Moratorium', Michael Cassidy (1976:267) argues that churches that have been colonised by those funding them, have a serious identity crisis. The other issue that comes with colonisation of the church is that, instead of serving God faithfully, the local pastors find themselves working to please their white masters. In one of the meetings it was reported that:

Zwi khagala nga maanda uri ri nga silavhelele thikhedzo ya tshelede ine ya nga bva kha dzinwe kereke ine ya nga nekedzwa kha itshi tshikolo zwino nga $u$ thavhanya. Vhanne vha nga ri tikedza nga tshelende vha re kha dzinwe kereke dza fhano shangoni lashu na dzi re seli vhanga kona u zwi ita tshifhingani tshi daho musi vha tshi vhona zwauri rine arikho ita zwa mahundwane. (It is very clear that we cannot expect any financial assistance from other churches to our theological school any time soon. Those who can assist us, whether it is the churches from our country or from countries abroad, will only start doing that when they realise that it is not a game that we are playing.) (Maambiwa 2004:127)

The very clear point here is that the motivation to work hard for the development of the theological school is to please the funders. Pleasing the giver, instead of pleasing God Himself, is a phenomenon dominating dependent church pastors and ministers. This is exactly in line with Oduyoye's articulation (in Madise 2013) that the black church is accepting standards that were set for them without their participation. According to my knowledge, the called NEVEFMA (abbreviation of some churches in Soutpansberg Synod, Venda) is the body which is the only bridge through which any congregation can create relationships with the Christelijke Gereformeerde Kerk in Holland with the purpose of asking any form of assistance. This was the same way in which colonies were formed (Baloyi 2011a).

\section{Poor image for black theologians}

In Steve Biko's language (1978:28) black people were reduced to nothing but shells of themselves and the black man has even lost his manhood. The history of black people's dislocation clearly made them underdogs in the churches to which they belong (Biko 1978:63). In Maluleke's view (1998), black pastors (regardless of their age) have become 'boys' who serve the interest of the white man's church in the black community. Even if the tradition is that the African black male is a leader who makes decisions in the house, his 'outof-the-box' thinking is very limited, non-existent and not tolerated at all (Ashimolowo 2007:272). This inequality was regarded: even if the black man was more qualified than his white counterpart, he remained a minor.

Most ministers that are supported by white churches, whether locally or abroad, have 'developed a low estimation of themselves, saddled with doubts and uncertainties about themselves in the eyes of their supporting masters' (Opoku 2009:7). In order to convince the giving church to pump more money into the local church accounts, the pastor should listen unconditionally to the funder. The black ministers become shadows of the white missionaries in their own churches (Mbiti in Cassidy 1976:268).

\section{Self-hatred, divide and rule system}

Professor Takatso Mofokeng (1988:35), argued self-hatred and said: 'In order to do black theology one needs to first love blacks, but blacks are not lovable'. The unlovable part of us can, for the most part, be attributed to an irredeemable selfhatred, which Opoku (2012:4) extensively discusses in his paper entitled: 'Skinny, but imperishable'.

One of the weapons used by apartheid was to apply the colonial practice of 'divide and rule', which was entrenched when the homelands were formed. A lot has been done to ensure that those homelands become enemies towards one another. I quote Opoku, who once said:

A seemingly lasting effect of missionary teaching is the uneasy attitude, nay the fear most African Christians have about their culture and the timorously hesitant approach of the church to most things African. (Opoku 2009:14)

This corresponds with the opinions of Ashimolowo (2007:271), who believes that the colonial education ensured that black ethnic groups undermined and subjugated one 
another. It is still very evident that in the very same Reformed Church, black ethnic groups are up against each other because of these divides. According to the report of the Classis $^{5}$ Limpopo, there are very clear indications that the white church became successful in using their money to divide and cause conflict between the black churches when it reports:

Out of the conversations with the scribe of the article 48 deputies (Synod Potchefstroom and the article 48 deputies of Synod Soutpansberg) it seems that there is no clarity on the exact nature of the relationship between the two synods (as well as the relationship between congregation in the two synods). On one level there are for example bitter disputes, but on another level there is a co-operation in mission work. To which of the two synods will the new converts connect up? On this issue there is already uncertainty in the Pietersburg area. (Aannvullende Agenda 2008:3)

By funding both black churches from different synods to do mission in the same territory, the giving church succeeded in getting the black churches against each other. The divideand-rule approach was central to the apartheid strategy, to break the united power of the black people. Black brothers became enemies, competing with one another for a white church subsidy. It does not matter how old the black minister is, as long he is still dependent upon the white church for his survival, he remains a 'boy' who works for them. Tshaka (2013:189) gives a clear picture of this when arguing that the paramount issue for the slave-master to be successful is that they should capitalise on the differences that exist between the slaves which will enable hem to control the slaves. This practice is what we read on the previous paragraph.

The black man's church 'hangs its dirty linen out' for the white church by giving all reports and challenges, which informs the white church about their experiences. But the black church knows or demands no information from the white church. The budget and plans for the black church are not secret for a white church. Problems and challenges of the black congregation are addressed by the givers and funders even before they are addressed by the local church administration or church council. As an African, I am still convinced that my family issues cannot be addressed by the local chief or by kinfolk unless it is addressed in the household first by way of consultation.

\section{Way forward, recommendations and suggestions The praxis of reconciliation and redress of the past racial inequality}

Denton (1991:105) once said in one of his sermons: 'The Berlin wall may be down, but not everyone on the planet is yet free'. Without denying that apartheid had officially been abolished in South Africa, I cannot doubt that its impact and its effects are still not done with. Those who try to avoid and ignore the discussion about apartheid in pretence of its demise are trying to evade the challenges of our time. It is this kind of pathology which does not only need to be arrested, but also destroyed.

Avoiding speaking of the past in pretence that everything is well is very suicidal. I am of the opinion that the Truth and Reconciliation Commission which was led by Desmond Tutu played its role, but the Reformed churches should have taken a step further by addressing issues that divided them in order to find reconciliatory possibilities. The Reformed churches might have worked on their structural unity based either on geographical settings and so on, but issues of reconciliation for me are still a serious and unattended hindrance, hence the inequality practices are still prevailing. Theories of reconciliation had been debated in many angles, but the praxis of reconciliation in the church, in which the truth, mercy, justice and peace meet, still needs our theological reflections. In his book: 'Building peace' Lederach provides foundational ideas and innovative practical tips for achieving reconciliation in divided societies.

The emotive, perceptual, social-psychological and spiritual dimensions of reconciliation remain our concern (Lederach 1998:29). Black and white churches which were set apart by apartheid need these issues be raised and deliberated without prejudice or fear for the sake of true reconciliation. It is my contention that if this does not happen, a black Reformed Church will continue to exist at the mercy and toleration of the white Reformed Church for some decades to come. Snyman's point (2009:227) is correct: that the wrongness of the reading of the Bible which entrenched racial inequalities demands the correctness of the ethics of reading the Bible in order to reverse the situation.

\section{The liberation of the black church is now in the hands of the black church}

Maluleke's (1998:19) statement: 'Brother, you need to be transformed' tells a black theologian to actively play a role for the change. Some thought John Gatu, was extremely aggressive when he called for 'Missionaries to go home' (Anderson 1974:1). I personally think his situation did not perhaps give him other alternatives in search for the church's true identity. It is time the black church (theologians and ministers in particular) should deny and refuse co-operation and participation in their own dehumanisation (Cone \& Wilmore 1993:12).

It was for this reason that Christian organisations (e.g. the South African Student Organisation, University Student Movement, Bold Evangelical Christian Organisation), pushed the agenda of black consciousness, a clear indication that the Black Consciousness Movement (BCM) had its roots in Christian values (Kgatla 2013:130). This was aimed at making black people aware that they have a role in their liberation. It is in this context where black ministers, pastors and theologians are advised to emulate people like Kritzinger, 
Speckman and Kaufmann who became tent makers in order to set their congregations free from dependency (Baloyi 2010:431). There is an agreement, which I strongly support, between Ashimolowo (2007:271) and the Black Consciousness leader, Steve Biko, who argued that black people should determine their own destiny. It is in this context that black Africans themselves should take charge of their own theology with or without the financial support. It will not be easy but our ancestors left us an encouraging idiom: 'It does not matter how scorching is the sun, it will never rub the stripes of a zebra' (Opoku 2009:4).

\section{The pride of an African man is to be able to fend for his family}

An African man always took pride in the ability to provide and be a breadwinner of his family. Any failure to do so would render the man an unfit leader. The dependency attitude of the black ministers compromised their deserved respect from their own congregants, just like an African father whose dignity is deeply affected when failing to provide for his family. It is a contradiction to be 'boy' for the white church but suddenly a leader in a black church. Black leadership which is lacking in the theological arena cannot undermine this point.

\section{The role of the missionary church}

I am in full support of the example set by the decision of the Methodist missionaries in Uruguay in 1969 that to withdraw voluntarily was beneficial to both sides, the receiver and the giver (Anderson 1974:1). This church set a good example for other missionary churches to follow. However, the decision of missionaries to withdraw must be driven by love for the growing indigenous church, instead of fights and hatred. This will give the indigenous church an opportunity to search for its own identity and destination theologically. When the umbilical cord is cut and the child is set free, it is painful for the mother, but it is worth it. It had been evident that most missionary churches try to avoid this voluntary withdrawal, thinking that the indigenous churches are 'politically motivated and politically pre-occupied', but that is an assumption that cannot be proven (Cassidy 1976:270). It is for this reason that the All African Conference of Churches AACC was labelled and uncritically identified as the zealots of the early New Testament at the Lusaka debates of 1971. The voluntary withdrawal may also prevent unexpected bad relationships between the sending and receiving churches as well as the ecumenicity of the church. These are some of the possible problems John Gatu and others have identified in the moratorium debate.

\section{A need for a black Reformed theological paradigm?}

It will take few revolutionary minded Reformed theologians not only to think and write about challenges of the black church, but also to put what they write in practice, without fear or prejudice from their colonial white masters. Colonialism has ended officially, but its effects are still alive.
Arguments for theology to be in the African church, liturgics and traditions that are targets of change (Maluleke 2013:472) are evident, but without praxis. In support of Burger (2010:317), who was echoed by Baloyi (2011b:71), it is time the creativity of the Holy Spirit should come to play. If this will be labelled as revolution then it means Calvin was also revolutionary against the Catholic Church.

I am in agreement with Cassidy (1976:266) and Tshaka (2013:182) on a concern for a culturally relevant leadership, towards which the present theological seminaries and university education has turned a blind eye. Black theologians need to start identifying themselves with the black masses. In his thesis entitled: 'ommunal pastoral counseling: Culturally gifted care-giving in times of family bereavement', Dr Phaswana wrote about cultural pastoral care which acknowledges the involvement of aunts, uncles and even elders in a village in critical times. That is the way Africans dealt with their issues before they could consult expensive lawyers and legal courts.

Instead of avoiding and demonising engagements on issues of witchcraft, healing ministries, lobola (as a punishment when the wife dies) we need to start engaging on these issues theologically.

\section{Revolutionising the theology of giving}

It is has been my argument that, if the Pentecostal churches and African Independent Churches (AICs) are enjoying financial growth in the same socio-economic context alongside the perpetual Reformed beggars, then it is the theology and teaching of the church that keeps them poor (Baloyi 2011a:98). This is the way the so-called 'boys of white congregations' can be liberated to become real pastors who take charge and direct the black church to its desired destination (Maluleke 1998:20). I agree with Lou Havemann's suggestion when saying: 'No more hand-outs, no more subsidies; we need to stand with our own resources. It is time to teach and preach stewardship and our responsibility to give and support the work of the church' (quoted in Maambiwa 2004:122).

In the Old Testament giving has uncompromisingly been taught. The story of Melkhizedech in Genesis 14:18-20 indicates that tithing is 400 years older that the law or the Torah. The church from the beginning was administered by the resources from its own members. Jesus, about whom the very third sola is speaking, was firm on teaching people about giving. He openly said: 'Give to Caesar what is Caesar's and to God what is God's'. This taught the church to give (Mk 12:17). Baloyi (2011a:100) is correct that the bondage of inferiority and the move to liberation of the black church will only take place when the black pastors start true biblical teaching on giving. This is in support with what Steve Biko (1978) said, and I quote:

Liberation therefore, is of paramount importance in the concept of Black Consciousness, for we cannot be conscious of ourselves 
and yet remain in bondage. We want to attain the envisioned self which is free self. (p. 52)

The church must be taught that just as stewardship is incomplete without generosity, self-governing and freedom of the church is impossible without sacrificial giving. The African church should be taught to take pride in what they worked hard for. The Pauline letters include many teachings on generosity, for instance 2 Corinthians 9:6-11. It is in this passage where Paul encourages cheerful giving as beng parallel to sowing and reaping. In 1 Thessalonians 4:12 Paul directly emphasises that giving in the church will help the church avoid being a burden. It is in line with this lecture that Paul encourages the giving which will liberate the congregation from being dependent on anyone.

\section{Conclusion}

The financial dependency of the black ministers, which is evident in the Reformed Churches, amongst others, does not only compromise their self-esteem and dignity, but also the contextualisation of the black church. It cannot be denied that the subsidies and support that the black church receives from the missionary church will continue to stunt their growth and their development. It will also compromise and undermine the culturally relevant leadership as well as the contextual role of the local church in the community. We need theology that will address the immediate challenges of the black masses. This can only happen if we are liberated from the bondage of an inferiority complex. The concept 'autonomy' has its origin in the Greek language and is formed from two words, meaning 'itself and law'(Hanko 1996:16). That which is autonomous makes, executes and enforces its own laws and does so without outside interference. The Reformed Church (GKSA) is directly under the law of Christ and no other body or institution may come between it and Christ. Briefly, this is self-governing under the rule of Christ. That is why the Reformed Church under discussion chose to do away with bishops and popes. If nothing is done it will be those with money (or perhaps without faith), who will continue to make decisions for the Reformed Church.

Allow me to close this article with a quote from Lines (2008), who says:

The selfhood of the church means that a church is fully responsible for managing its own life, for discerning the nature and demands of its own mission, for sustaining this mission with its own faithfulness and sacrifice and joy, for evolving a form and style of life which expresses its own identity as God's people in a particular sector of the world. (p. 6)

\section{Acknowledgements Competing interests}

The author declares that he has no financial or personal relationships which may have inappropriately influenced him in writing this article.

\section{References}

Aannvullende Agenda, 2008, 'Partikulêre Sinode Bosveld van Gereformeerde Kerke', Gerformeerde Kerk Potgietersrus.

Adamo, D.T. \& Enuwosa, J., 2004, 'Missionaries go home: The integrity of mission in Africa', paper presented at the International Conference of the International Association for Mission Studies, Port Dickson, Malaysia, 31 July - 07 August.

Allen, R., [1912] 1960, Missionary methods: St Paul's or ours? World Dominion Press, London.

Anderson, G.H., 1974, 'A moratorium on missionaries?' in G.H. Anderson \& T.F. Stransky (eds.), Mission Trends 1, pp. 133-142, Paulist Press, New York.

Ashimolowo, M., 2007, What is wrong with being black. Celebrating our heritage, confronting our challenges, Destiny Image Publishing, Inc., Shippensburg.

Baloyi, M.E., 2010, 'The sustentasie problem in the Reformed churches of South Africa: Unmasking the dilemma facing the black theologians', International Journal of Bible, Religion and Theology in Southern Africa 105, 421-433.

Baloyi, M.E., 2011a, 'The ethics of giving as a liberation vision for the wellbeing of the black Reformed churches', Journal of Theology and Religion in Africa 35(1), 96-117.

Baloyi, M.E., 2011b, 'Church unity and justice in the Gereformeerde Kerke in South Africa: Perspectives from Soutpansberg Synod between 2003 and 2008', Studia Historiae Ecclesiasticae 37(1), 59-75.

Baloyi, M.E., 2014, 'A pastoral examination of the Christian Church's response to fears of and reactions to witchcraft amongst African people in the Limpopo province of South Africa', HTS Teologiese Studies 70(2), Art. \#1317, 9 pages. http://dx.doi. org/10.4102/hts.v70i2.1317

Banda, Z.J., 2009, 'Solidarity with victims. An appraisal of JNJ (Klippies) Kritzinger's contribution to the praxis of Liberation Theology', Missionalia 37(3), 111-124.

Burger, C.W., 2010, 'Calvin and the unity of the church: Relevance for the Reformed Churches in South Africa', Nederduitse Teologiese Tydskrif 51, 313-320.

Biko, S., 1978, I write what I like, Macmillan, Johannesburg, South Africa.

Cassidy, M., 1976, 'The call to moratorium. Perspectives on identity crisis', Churchman articles, 265-280, viewed 01 April 2016, from www.churchsociety.org.

Cone, J.H. \& Wilmore, G.S., 1993, Black theology. A document documentary history volume one: 1966-1979, Orbis Books, Maryknoll, NY.

Denton, D.G., 1991, Challenging sermon outlines, Baker Book House, Grand Rapids, MI.

Deventer, H.J.M., 2005, 'Why minds are changed: An inquiry into the decisions by the Gereformeerde Kerke in Suid Afrika (GKSA) on the role of women in the church', Koers 70(4), 685-704. http://dx.doi.org/10.4102/koers.v70i4.288

Die Almanak van die Gereformeerde Kerke in Suid Afrika vir die jaar 2015, V \& R Drukkery, Pretoria.

Du Plooy, A le R., 2003, Reformed church polity. Essays and topics, Die Teologiese Skool van die Gereformeerde Kerke in Suid Africa, Potchefstroom.

Gijswijt-Hofstra, M., 1999, Witchcraft after the witch-trials, Athlone Press, London.

Hanko, H.C., 1996, 'The autonomy of the local church', Protestant Reformed Theological Journal 30(1), viewed n.d. from http://www.prca.org/prtj/nov96.html

Lederach, J.P., 1998, Building peace. Sustainable reconciliation in divided societies, United States Institute of Peace, Washington, DC

Lekalakala, M.J., 2002, 'Synod Midlands, reforming or deforming?', Unpublished paper circulated amongst Reformed Church ministers.

Lines, K.P., 2008, 'Missionary go home: The moratorium call, updated \& shorter', November 2008, 610, viewed 20 July 2012, from http://hiu.academia.edu/ KevinPLines/Papers/614483/The Continued Importance of a_Mission KevinPLines
Moratorium

Kgatla, S.T., 2013, 'Forced removals and migration: A theology of resistance and liberation in South Africa', Southern African Journal of Missiology, 41(2), 120-132.

Kiyosaki, R.T., 2012, Rich dad Poor dad. What the rich teach their kids about moneythat the poor and middle class do not, Plata Publishing, Scottsdale.

Maambiwa, Minutes of Soutpansberg Synod, 2004, pp. 122 \& 127.

Madise, M.J.S., 2013, Borrowed/Begged water never quenches thirst, Inagaural lecture delivered at Unisa, Pretoria.

Manala, M.J., 2009, 'Worship in the Maranatha Reformed Church', Unpublished paper prepared for the Synod of the Maranatha Reformed Church, Ontario.

Manala, M.J., 2015, 'A therapeutic community as a relevant and efficient ecclesial model in African Christianity', Unpublished inaugural lecture delivered on 20 May 2015 at Unisa, Pretoria.

Mashele, P., 2014, 'Status of blacks as servants unchanged. Whites allow inequality, racial privilege to go on', The Sowetan, 8 December, p. 11.

Maluleke, S.D., 1998, Guide for financial stewardship. Giving in the church, CLF Uitgewers, Bloemfontein.

Maluleke, T.S., 2013, 'Half century of African Christian theologies: Elements of the emerging agenda for the twenty-first century', Chapter 18 submitted digitised by University of Pretoria, Library Services, pp. 469-494, Journal of Theology for Southern Africa.

Modise, L., 2011, 'Black church buildings that are still on white churches' land: A land restitution perspective', Studia Historiae Ecclesiasticae 37(1), 221-236.

Mofokeng, T., 1988 'The black Christians, the Bible and liberation', Journal of black Theology 2(1988), 34-42. 
Opoku, K.A., 2009, 'Cooking on two stones of the hearth: African spirituality and the socio-cultural transformation of Africa', Journal of Christian Thought 13(1), $3-9$.

Opoku, K.A., 2012, 'Skinny but imperishable truth: African religious heritage and the regeneration of Africa', Studia Historiae Ecclesiasticae 38(supplement), the regener.

Ramantswana, H., 2015, 'Theological training in the black Reformed Churches in South Africa RCSA)', In die Skriflig 49(1), Art. \#1814, 17 pages. http://dx.doi. org/10.4102/ids.v49i1.1814

Snyman, G., 2009, ‘David and Shimei: Innocent victim and perpetrator? The ethics of reading the Bible', Missionale Theologie xx(x), 223-251.

Speckman, M.T. \& Kaufmann, L.T., 2001, Towards and agenda for contextual theology, Cluster Publications, Pietermarizburg.

Strawbridge, G., 1993, 'The five solas of the Reformation', viewed 27 August 2015, from www.fivesolas.com.
Theron, J. \& De Wit, J., 2009, 'Can charismatics be Calvinists? New trends within charismatic circles with special reference to the situation in South Africa', Studia Historiae Ecclesiasticae 36(2), 153-167.

Tshaka, R.S., 2009, 'Academic theology as the yardstick of being Reformed in South Africa today: An appreciative critique of Calvin on the occasion of his 500th birthday', Journal of Church History Society of Southern Africa 36.

Tshaka, R.S., 2013, 'Do our theological methodologies help us to deal with situations of violence in black communities, specifically Afrophobia?', Journal of Theology for Southern Africa 138, 124-135.

Van Wyk, J.H., 2010, 'To cross ten seas: Calvin on the unity of the church - a contribution to a more responsible ecclesiology', In die Skriflig 44(2), 301-316. http://dx.doi.org/10.4102/ids.v44i2.148

Vine, W.E., 1981, Expository dictionary of Old and New Testament words, Fleming and Revell, Grand Rapids.

Waruta, D.W. \& Kinothi, H.W., 2000, Pastoral care in African Christianity. Challenges and essays in pastoral theology, Acton Press, Nairobi. 